\title{
Retinoblastoma pT4b TNM Finding v7
}

National Cancer Institute

\section{Source}

National Cancer Institute. Retinoblastoma pT 4b TNM Finding v7. NCI Thesaurus. Code C88738.

Retinoblastoma with tumor invading optic nerve to resection line and extra-ocular extension is identified. (from AJCC 7th Ed.) 